International Journal of Informatics, Economics, Management and Science

http://journal.stmikjayakarta.ac.id/index.php/ijiems

E-ISSN: 2809-8471 (online), P-ISSN: 2809-9281 (Print)

DOI: $10.52362 /$ ijiems.v1i1.678

Volume 1, Issue 1, January 2022, page 13-31

\title{
Application of expert system diagnosis of color blindness with ishihara
} method with microsoft vb 6.0

Verdi Yasin $^{1^{*}}$, Peniarsih ${ }^{2}$, Achmad Gozali ${ }^{3}$, Ifan Junaedi 4

${ }^{1,3,4}$ Department Informatics Engineering, STMIK Jayakarta, Jakarta, Indonesia

${ }^{2}$ Department Information System, Universitas Dirgantara Marsekal Suryadarma, Jakarta, Indonesia

Authors Scopus ID URL:

Verdi Yasin ${ }^{{ }^{*},}$ https://www.scopus.com/authid/detail.uri?authorId=57215307401

\section{Email address:}

Verdiyasin29@gmail.com, ppeniarsih@yahoo.co.id, ifn1809jn@yahoo.co.id

*Corresponding author : verdiyasin29@gmail.com

Received: November 30, 2022; Accepted: December 22,2022 ; Published: January 8,2022

Abstract: Application Expert System Diagnosis of Color blindness using the Ishihara Method With Microsoft VB 6.0 is a system that makes it easier to diagnose eye disease (color blindness). In developing engineering systems the development of expert system application applications. To facilitate the development of this program application, Researchers use modeling/designing flow chart tools or structured modeling. And designing input systems in the form of Interface Design related mechanisms for the use of applications of this expert system.

Keywords: Expert_System, Color_blindness, Ishihara Method

\section{Introduction}

In the era of globalization, computer technology is increasingly sophisticated and

It is growing rapidly, especially Information Technology (IT) which has been used by many people to manage information from various professions. A computer is a tool Useful to facilitate a job from a field of work such as medicine, education, business, banking, industry, and so on. In this case, the author wants to create a program from the implementation of the expert system through the Ishihara method that diagnoses a person's eye health condition by testing in the form of models of colored letters and numbers disguised with other colors can be in the form of dots or lines in one scope of the problem.

In line with this, the rapid development of the industry also encourages writers to create programs in terms of diagnosis of eye disease (color blindness) which has been in the form of manual problems, has not been computerized so that the results can be directly stored in the data base of industry or hospital, especially in terms of new employee admissions.

Scope of the problem that will be discussed in the research, this is to develop a system, especially in the creation of microsoft visual application programming basic 6.0 and to diagnose 
International Journal of Informatics, Economics, Management and Science

http://journal.stmikjayakarta.ac.id/index.php/ijiems

E-ISSN: 2809-8471 (online), P-ISSN: 2809-9281 (Print)

DOI: $10.52362 /$ ijiems.v1i1.678

Volume 1, Issue 1, January 2022, page 13-31

eye disease (color blindness) in a person that can only be known after the person follows several tests with this program. With the concept that will be developed is the presentation of the results of existing health tests that are still manual not using a computerized system, the time of presentation manually becomes less efficient compared to using software (computer programs), This program is expected to help especially the medical parties in maximizing the results provided, can save time, especially from the collection of new prospective employees in order to pass health tests. Researchers developed the results of this study in order to build an application of color blindness diagnostic program in the human eye, so that it can be welcomed by many people not only job seekers who can feel it, but all and can take the test whenever they want.

The purpose of this research is to build a system, to make it easier to diagnose color blindness that occurs in someone who is feeling it, Provide maximum service to people with eye diseases, especially diagnose using the application of the program that will be available and Provide effective and efficient color blindness diagnosis services to people experiencing the suffering.

\section{Materials and Method}

\subsection{User Interface}

The linking section between the expert system program and the user allows the user to interact by entering instructions and information into the expert system and receiving writing and conclusions, which then determine the parameters by leading to the expert system through the process of reasoning. The information is in the form of values assigned to a particular variable.

\subsection{Knowledge Base}

At the core of the expert system, this knowledge base consists of a collection of objects and their rules and attributes, for example:

IF the aircraft is wingless and there are propellers

THEN helicopter type aircraft.

The knowledge base contains facts both the initial facts at the time the system was operating and the facts at the time the conclusion was being made. The term problem domain is used to describe the problem area and as long as the expert system operates the database is in working memory.

\subsection{Inference Engine}

The part that provides the mechanism of the function of thinking, the patterns of reasoning systems used by an expert, provides reasoning skills that interpret the contents of the Knowledge Base part of the expert system that performs reasoning using knowledge base based on a specific order. This mechanism will analyze a particular problem and will then look for the best answers and conclusions.

Deductively the interensi machine selects the relevant machine in order to reach a conclusion. Thus the system can answer the user's question even if the answer is not explicitly stored in the knowledge base, the inference machine begins tracking it by matching the rules in 
International Journal of Informatics, Economics, Management and Science

http://journal.stmikjayakarta.ac.id/index.php/ijiems

E-ISSN: 2809-8471 (online), P-ISSN: 2809-9281 (Print)

DOI: $10.52362 /$ ijiems.v1i1.678

Volume 1 , Issue 1 , January 2022, page 13-31

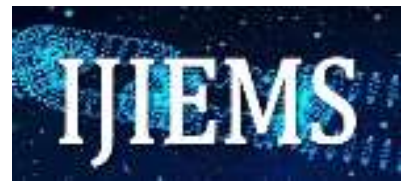

the knowledge base with the facts contained in the database. Here are two types of inference techniques:

1. Backward chaining tracker that starts its reasoning from a set of hypotheses to the facts that support the hypothesis.

2. Forward chaining which is the opposite of backward tracking, which starts from a set of data to a conclusion. The following can be seen tracking diagrams that can be used in the inference machine mechanism.

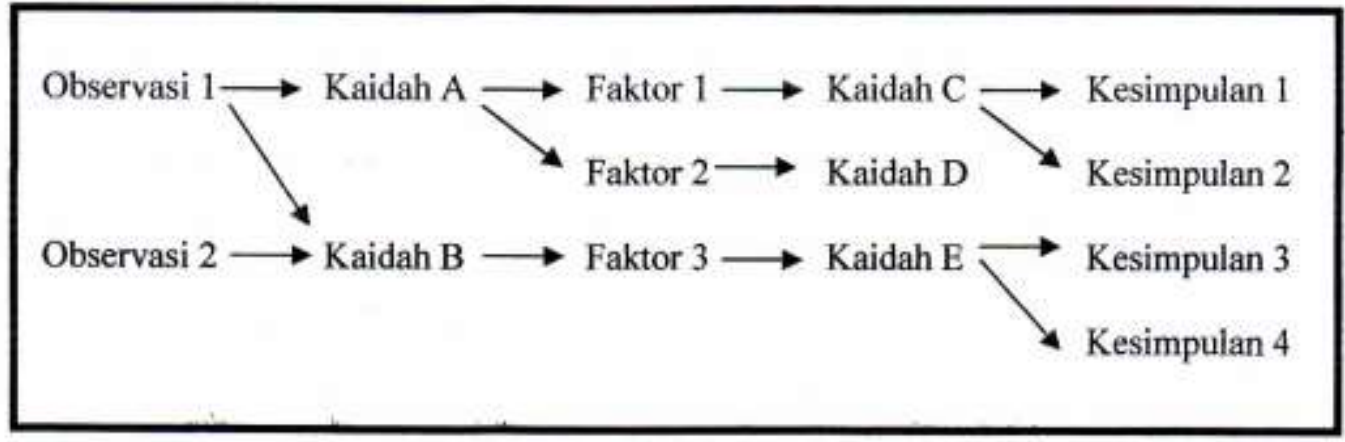

Figure 2.1 Rear tracking (in Indonesian)

Information Figure 2.1 :

- Observation (Observasi)

- Norm (Kaidah)

- Factor (Faktor)

- Conclusion (Kesimpulan)

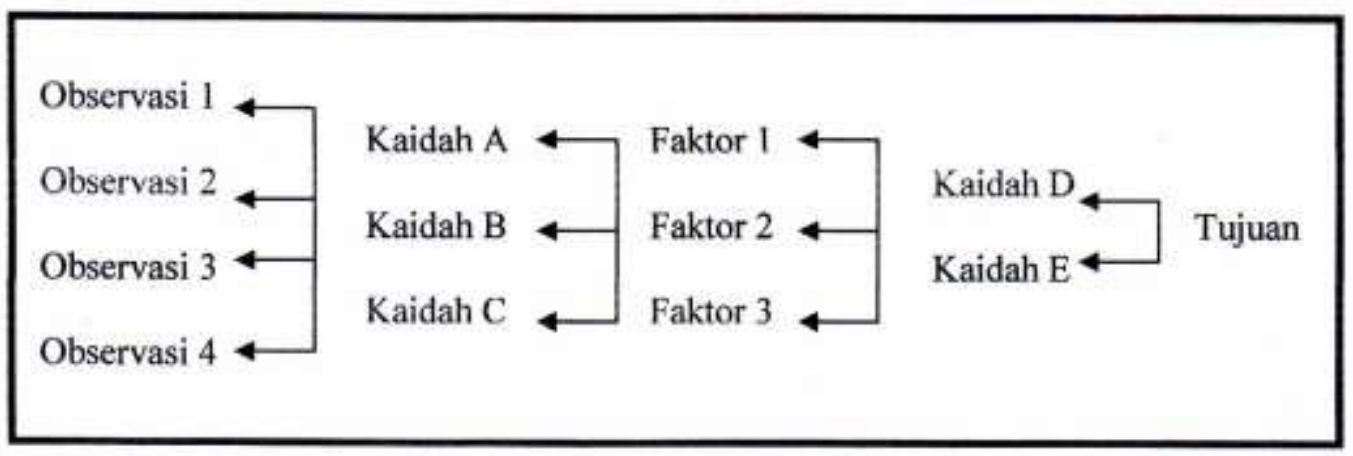

Figure 2.2 Forward tracking (in indonesian)

Information Figure 2.1 :

- Observation (Observasi)

- Norm (Kaidah)

\section{(c) (i) DOI: 10.52362 /ijiems.v1i1.678}

IJIEMS This work is licensed under a Creative Commons Attribution 4.0 International License. 
International Journal of Informatics, Economics, Management and Science

http://journal.stmikjayakarta.ac.id/index.php/ijiems

E-ISSN: 2809-8471 (online), P-ISSN: 2809-9281 (Print)

DOI: $10.52362 /$ ijiems.v1i1.678

Volume 1, Issue 1, January 2022, page 13-31

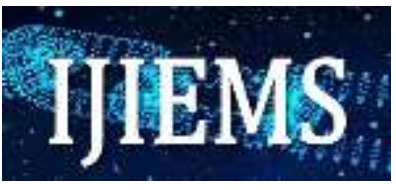

- Factor (Faktor)

- Conclusion (Kesimpulan)

Both inference methods are influenced by three types of search techniques, namely depth-first search, breadth-first search, and best-first search. Depth-first search is a deep search of the rules of the root node moving down to a level in sequence. Breadth-first search moves from the root node, the node that exists at each level is tested before moving to the next level. Best-first search works based on a combination of the two previous methods.

\subsection{Development Engine}

The main component of the four expert systems is the development engine, which is used to create expert systems, basically this process involves the creation of a set of rules, there are two basic approaches, namely:

1. Programming language ; We can create expert systems using any programming language, but some are perfectly compatible with symbolic representations of the knowledge base.

2. Shell expert systems; Expert system shell is a ready-made processor that can be customized for specific domain problems through the addition of the appropriate knowledge base. In many cases the shell can produce expert systems faster and easier than programming.

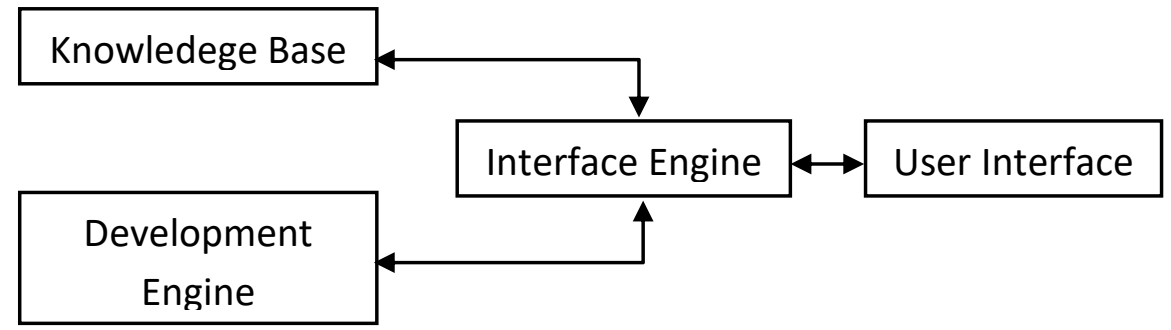

Figure 2.3 Expert System Model

In the design of this process will be applied how the application program process is currently run. Below is the process flow of the expert system of color blindness diagnosis of the human eye. 
International Journal of Informatics, Economics, Management and Science

http://journal.stmikjayakarta.ac.id/index.php/ijiems

E-ISSN: 2809-8471 (online), P-ISSN: 2809-9281 (Print)

DOI: $10.52362 /$ ijiems.v1i1.678

Volume 1, Issue 1, January 2022, page 13-31
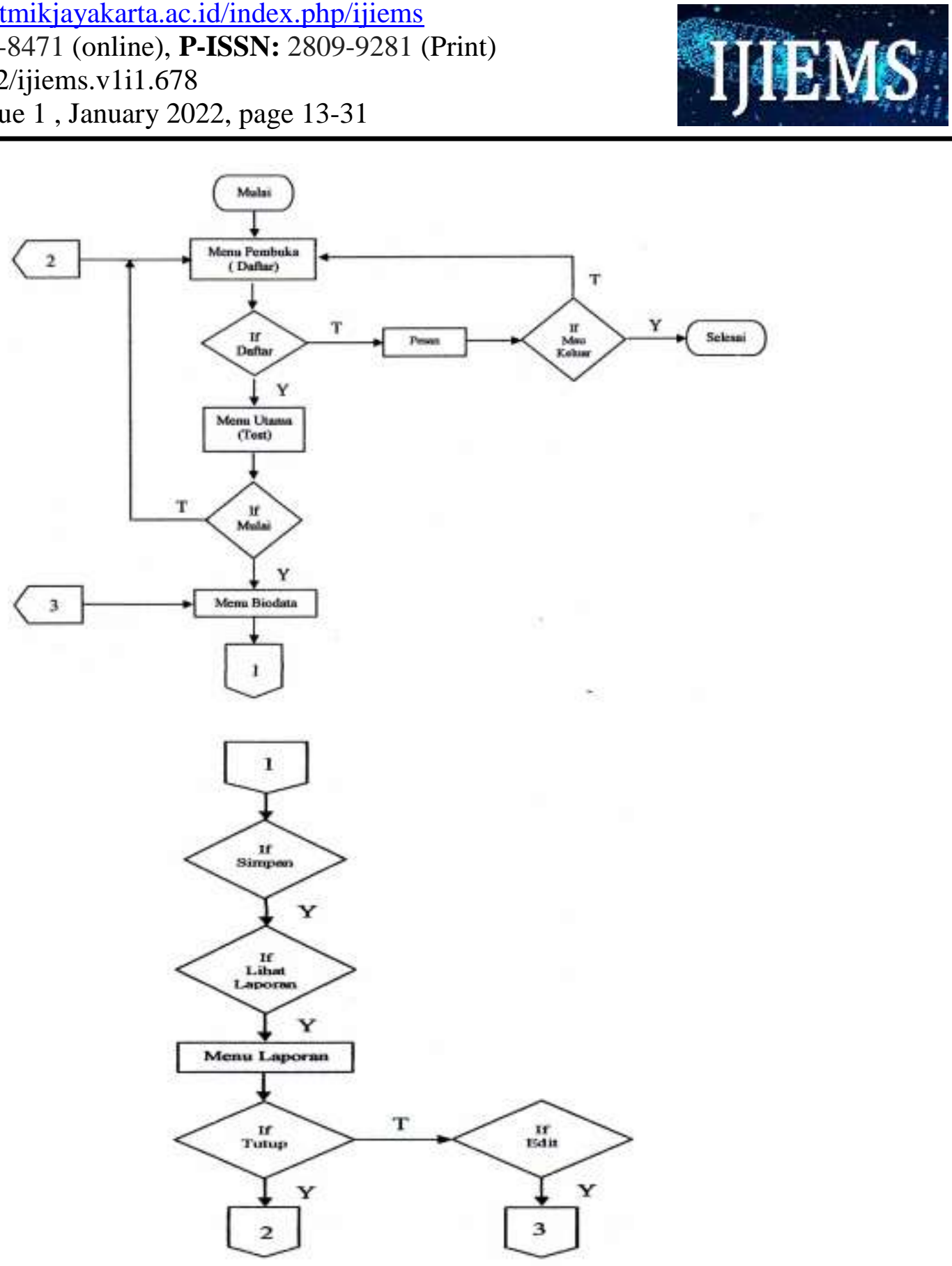

. Figure 2.4 Flowchart application program (in indonesian) 
International Journal of Informatics, Economics, Management and Science

http://journal.stmikjayakarta.ac.id/index.php/ijiems

E-ISSN: 2809-8471 (online), P-ISSN: 2809-9281 (Print)

DOI: $10.52362 /$ ijiems.v1i1.678

Volume 1 , Issue 1, January 2022, page 13-31

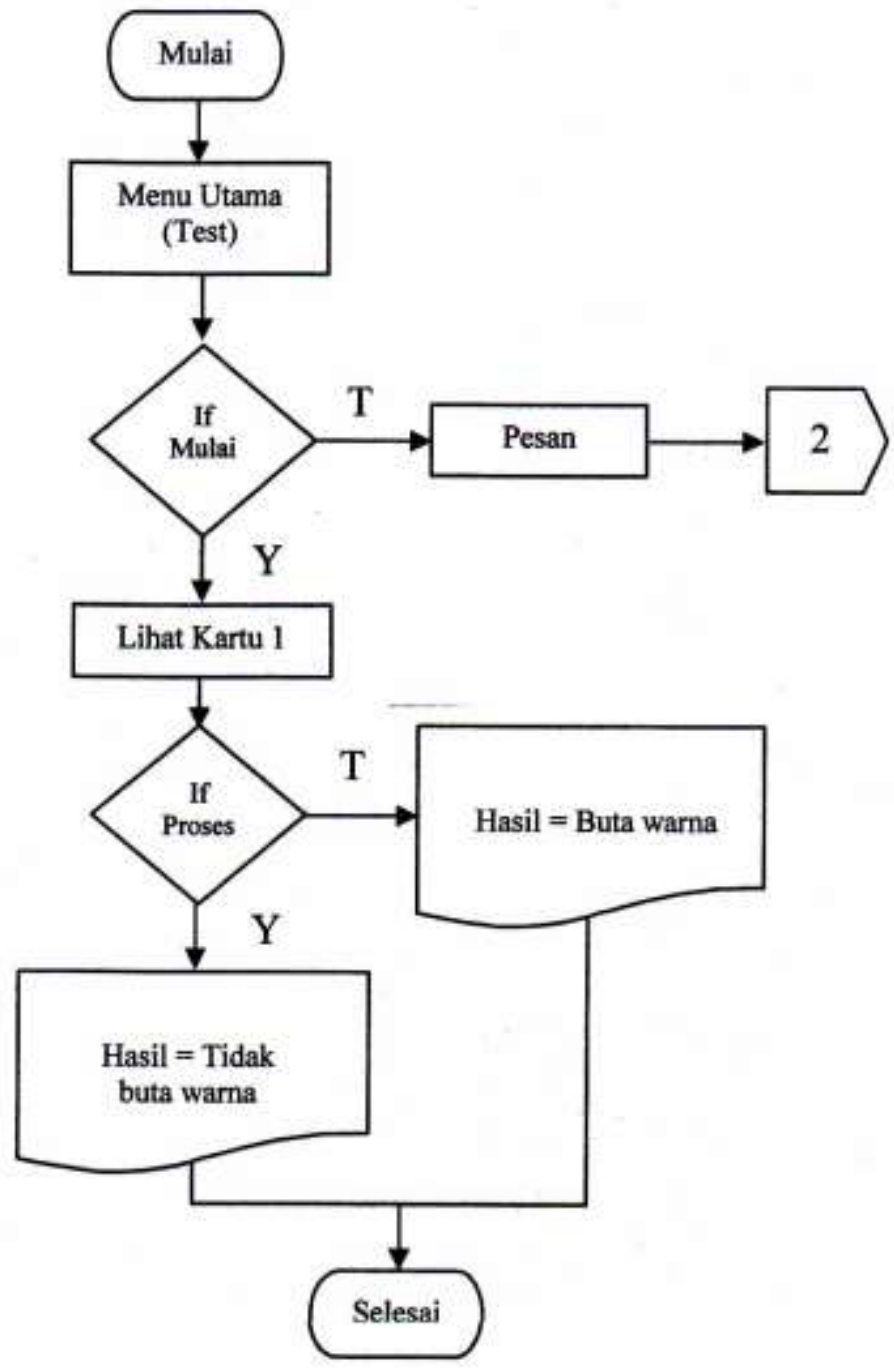

Figure 2.5 Flowchart Main menu (Test)

Based on existing data, the data will be used to compile the knowledge base based on the results of existing diagnoses, namely the knowledge base of color blind diagnoses using the Ishihara method in the human eye.

DOI: $10.52362 /$ ijiems.v1i1.678

IJIEMS This work is licensed under a Creative Commons Attribution 4.0 International License. 
International Journal of Informatics, Economics, Management and Science

http://journal.stmikjayakarta.ac.id/index.php/ijiems

E-ISSN: 2809-8471 (online), P-ISSN: 2809-9281 (Print)

DOI: $10.52362 /$ ijiems.v1i1.678

Volume 1, Issue 1, January 2022, page 13-31

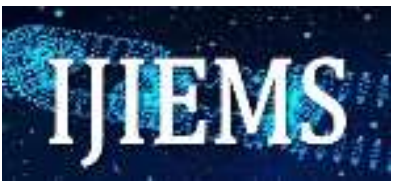

IF: the number that comes out is the number 5 (five)

THEN: participants fill in the numbers correctly

IF : problem = not guessing the number correctly

THEN : The solution is Level 8 color blindness is MONOCHROMACY which is the inability to form black-white-gray color caused by cone defects or absence occurs when two of the three cone pigments are missing which then becomes one dimension only and this is possible due to hereditary factors.

IF: the number that comes out is the number 49 (forty-nine)

TEHEN : participants fill in the numbers correctly

IF : problem $=$ not guessing the number correctly

THEN: The solution is Level 7 color blindness or TRITANOPIA is a very rare color vision disorder where there are only two cone pigments presenting from a total absence of the retina, where short wavelengths affect the inability to distinguish between colors in the yellow-blue part of various colors.

IF: the number that comes out is the number 8 (eight)

THEN: participants fill in the numbers correctly

IF : problem $=$ not guessing the number correctly

THEN : The solution is Your level 6 color blindness is colorblind with a trick to the end of the red color that leads to a reduction in sensitivity to the color green or so-called DEUTERANOMALY.

IF: the number that comes out is the number 6 (six)

THEN: participants fill in the numbers correctly

IF $:$ problem $=$ not guessing the number correctly

DOI: $10.52362 /$ ijiems.v1i1.678

IJIEMS This work is licensed under a Creative Commons Attribution 4.0 International License. 
International Journal of Informatics, Economics, Management and Science

http://journal.stmikjayakarta.ac.id/index.php/ijiems

E-ISSN: 2809-8471 (online), P-ISSN: 2809-9281 (Print)

DOI: $10.52362 /$ ijiems.v1i1.678

Volume 1 , Issue 1 , January 2022, page 13-31

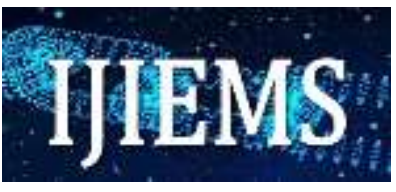

THEN: The solution is You level 5 color blindness is a color blindness PROTANOMALY is a soft color vision in which a spectral sensitivity altered by cells that are sensitive retinal stimulation especially red getting closer to the cell response sensitive to green stimuli that can result in the distinction of green color to be somewhat reddish, this can occur because coriander factors especially occur in women.

IF: the number that comes out is the number 45 (forty-five)

THEN: participants fill in the numbers correctly

IF : problem $=$ not guessing the number correctly

THEN : The solution is You level 4 color blindness is color blind with incompetence in the green-yellow-red color spectrum and results in not being able to distinguish light wavelengths from whites

IF: the number that comes out is the number 29 (twenty-nine)

THEN: participants fill in the numbers correctly

IF : problem $=$ not guessing the number correctly

THEN: The solution is You level 3 color blindness is color blindness PROTANOPIA is a lack of color vision caused by incompleteness of red retinal photoreceptors is a form of dichrommatism where the red appears dark and this is hereditary generally occurs in many men.

IF: the number that comes out is the number 56 (fifty-six)

THEN: participants fill in the numbers correctly

IF $:$ problem $=$ not guessing the number correctly

THEN: The solution is You are deuteranopic color blindness, which is the lack of cones at medium wavelengths or the inability to distinguish between colors in the green-yellow-red part of the spectrum, the neutral point of the three colors is found at the wavelength. As they see below the neutral point, generally this also occurs in only $1 \%$ of all men.

IF: the number that comes out is the number 2 (two)

THEN: participants fill in the numbers correctly

DOI: $10.52362 /$ ijiems.v1i1.678

IJIEMS This work is licensed under a Creative Commons Attribution 4.0 International License. 
International Journal of Informatics, Economics, Management and Science

http://journal.stmikjayakarta.ac.id/index.php/ijiems

E-ISSN: 2809-8471 (online), P-ISSN: 2809-9281 (Print)

DOI: $10.52362 /$ ijiems.v1i1.678

Volume 1, Issue 1, January 2022, page 13-31

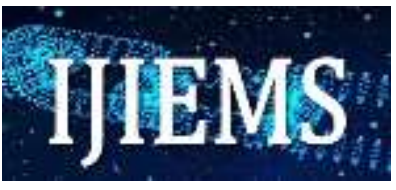

IF $:$ problem $=$ not guessing the number correctly

THEN: The solution is Level 1 color blindness is DEUPERANOPIA color blindness which is a lack of color vision in which green retinal photoreceptors do not exist, thus affecting the greenred color distinction and this is a form of dichrommatism in which there are only two cone pigments shown, generally this occurs in only $1 \%$ of all males.

IF $:$ problem $=$ guessing the number correctly

THEN: The solution is a You don't suffer from color blindness and take good care of your eyes. After the knowledge base above is well outlined, we can also use the knowledge base by using a tree (Tree) where the tree is a structure hierarchy consisting of nodes or nodes that store information or knowledge. Here's a picture of the decision tree from the knowledge base of color blindness diagnoses.

\section{Results and Discussion}

The system has several modules, consisting of opening menus, tests (problems), biodata, and reports. Each menu displays a form design that has not been executed or has not been executed by the program. This form relates to the steps that exist dialgoritma each menu

The display in the form of form design on this system consists of four displays. Namely the appearance of the opening menu, the appearance of the test menu (problem), the appearance of the biodata menu, and the appearance of the report menu. Figure 4.5 is the display of the opening menu (list) at the time the system starts running.

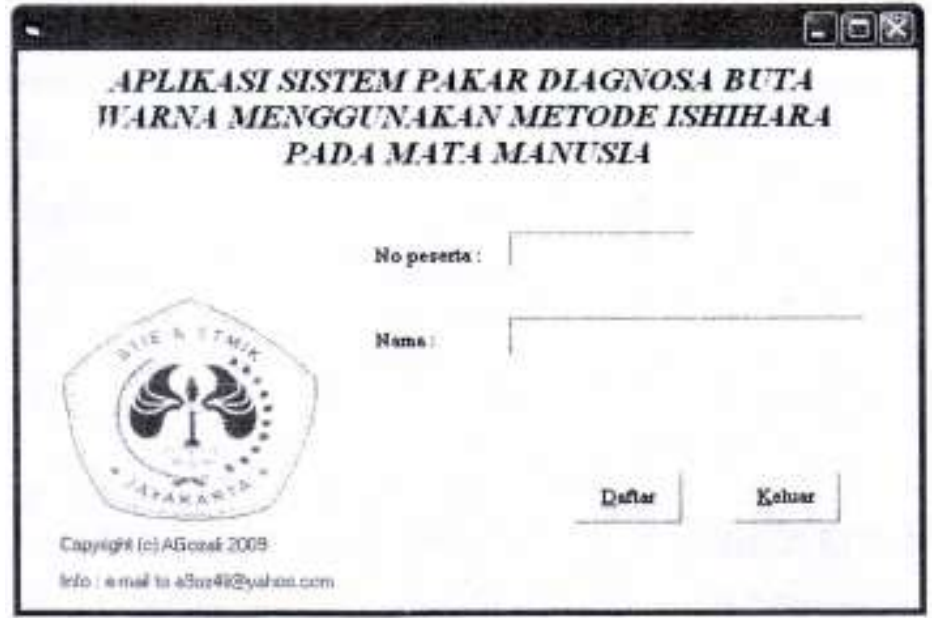

Figure 3.1 Opening Menu (in indonsian)

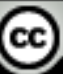


International Journal of Informatics, Economics, Management and Science

http://journal.stmikjayakarta.ac.id/index.php/ijiems

E-ISSN: 2809-8471 (online), P-ISSN: 2809-9281 (Print)

DOI: $10.52362 /$ ijiems.v1i1.678

Volume 1, Issue 1, January 2022, page 13-31

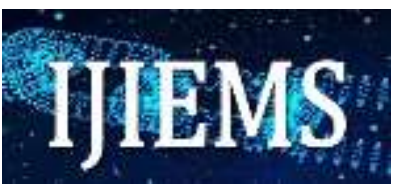

The form containing the opening menu will appear first when the system starts running. In the opening module there will be several procedures used including, the first step fills in the participant's name and the participant number will be directly filled in sequence and if the participant's name has not been filled, a warning message will appear. The program code in this opening menu will be shown as follows as well as how to connect it to the database:

Public NoPer As String

Public Nama As String

Dim rs_data As New ADODB.Recordset

Private Sub CmdDaftar_Click()

If $\mathrm{L}$ en(Text2.Text) $>0$ Then

NoPer $=$ Textl

Nama $=$ Text 2

Test. Show

Unload Me

Else

MsgBox "Tulis Nama peserta Anda!!!", vblnformation, "Peringatan!!!"

Text2.SetFocus

End If

End Sub

Private Sub Form_Load()

Adodcl.ConnectionString="Provider=Microsoft.Jet.OLEDB.4.0;Persist

Security Info=False;Data Source ${ }^{\wedge} " \&$ App.Path \& "IDatabasel.mdb"

Adodc1.RecordSource="SELECT * FROM table 1 order by NoPer"

Adodcl.Refresh

Set rs_data $=$ Adodcl.Recordset

Textl = rs_data.RecordCount +1

End Sub

In this test menu directly displayed form about the form of stuffing starting by displaying the card one by one, filling in the answer (input box) what number is displayed after completion it will display the message, it will automatically display the biodata menu form and keep in mind that in filling the answer is limited by time when the time has run out then the message will be displayed, It will automatically return to the original menu.

Below is the program code when the test menu is run

Dim klik As Boolean

Dim klik As Boolean

DOI: $10.52362 /$ ijiems.v1i1.678

IJIEMS This work is licensed under a Creative Commons Attribution 4.0 International License. 
International Journal of Informatics, Economics, Management and Science

http://journal.stmikjayakarta.ac.id/index.php/ijiems

E-ISSN: 2809-8471 (online), P-ISSN: 2809-9281 (Print)

DOI: $10.52362 /$ ijiems.v1i1.678

Volume 1, Issue 1, January 2022, page 13-31

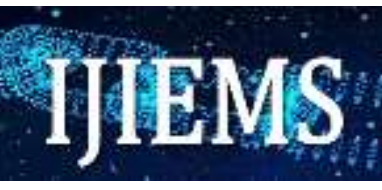

Dim isi As Boolean

Dim i As Integer

Dim k(I To 8) As String

Private Sub CmdMulai_Click()

Timer1. Enabled $=$ True

Textl. Enabled $=$ True

Textl.SetFocus

Image2. Visible $=$ False

Image 1.Picture = LoadPicture(App.Path \& "\2.jpg") $i=0$

End Sub

Private Sub Form_Load()

Image1.Picture = LoadPicture(App.Path \& "\3jpg")

End Sub

Sub benar()

Image2. Visible $=$ True

Image2.Picture = LoadPicture(App.Path \& "\Benar.jpg")

End Sub

Sub salah()

Image2. Visible $=$ True

Image2.Picture = LoadPicture(App.Path \& "\Salah.jpg")

End Sub

Private Sub Textl_KeyDown(KeyCode As Integer, Shift As Integer)

If Trim(Len(Textl)) >0 Then

If KeyCode $=$ vbKeyReturn Then

$\mathrm{i}=\mathrm{i}+\mathrm{I}$

Select Case i

Case 1

If Textl.Text = "2" Or UCase $($ Trim(TextI)) = "DUA" Then

benar

Else

salah

End If

$k(I)=$ Textl.Text Image 1.Picture = LoadPicture(App.Path \& "\56.jpg") 
International Journal of Informatics, Economics, Management and Science

http://journal.stmikjayakarta.ac.id/index.php/ijiems

E-ISSN: 2809-8471 (online), P-ISSN: 2809-9281 (Print)

DOI: $10.52362 /$ ijiems.v1i1.678

Volume 1 , Issue 1, January 2022, page 13-31

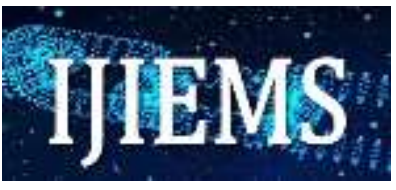

Text 1.Text $=$ ""

\section{Case 2}

If TextI.Text $=$ "56" Or UCase $($ Trim $($ TextI $))=$ "LIMA PULUH ENAM" Then

benar

Else

salah

End If

$k(2)=$ Textl.Text

Image1.Picture = LoadPicture(App.Path \& "\29.jpg")

Textl.Text = ""

Case 3

If Text1.Text $=$ "29" Or UCase $($ Trim(Textl)) = "DUA PULUH SEMBILAN" Then benar

Else

salah

End If

$k(3)=$ Textl.Text

Image 1.Picture = LoadPicture(App.Path \& "\45.jpg")

Text1.Text=""

Case 4

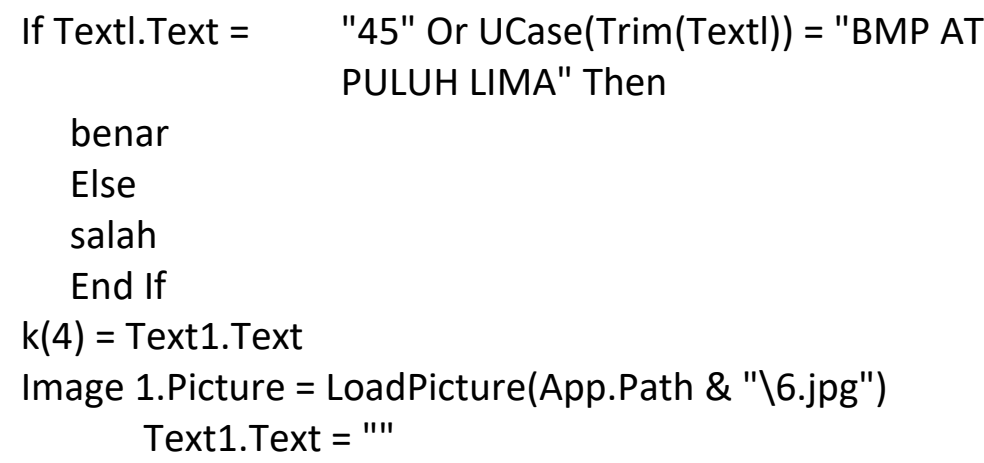

Case 5

If Textl.Text = "6" Or UCase(Trim(Text1)) = "ENAM" Then

benar

Else

salah

End If 
International Journal of Informatics, Economics, Management and Science

http://journal.stmikjayakarta.ac.id/index.php/ijiems

E-ISSN: 2809-8471 (online), P-ISSN: 2809-9281 (Print)

DOI: $10.52362 /$ ijiems.v1i1.678

Volume 1, Issue 1, January 2022, page 13-31

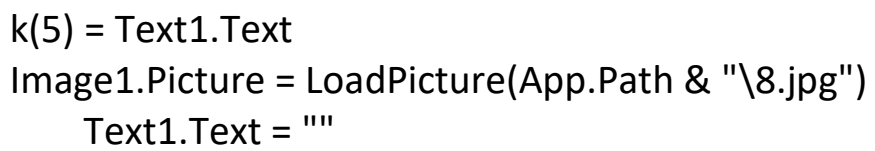

Case 6

If Text1.Text = "8" Or UCase $($ Trim(Textl)) = "DELAPAN"

Then

Benar

Else

Salah

End If

$k(6)=$ Textl.Text

Image 1.Picture = LoadPicture(App.Path \& "\49.jpg")

Text1.Text = ""

Case 7

If $(\operatorname{Trim}($ Text1. Text $))=$ "49" Or UCase $(\operatorname{Trim}($ Text. Text $))=$

"EMPAT PULUH SEMBILAN" Then

benar

Else

salah

End If

$k(7)=$ Text1. Text

Image1.Picture = LoadPicture(App.Path \& "V5.jpg")

Text1.Text $=$ ""

Case 8

If Textl.Text $=$ "5" Or UCase $($ Trim $($ TextI $))=$ "LIMA" Then

benar

Else

Salah

End If

$k(8)=$ Text1. Text

Text1.Text=""

Text1.Enabled $=$ False

Hasil

End Select

End If

DOI: $10.52362 /$ ijiems.v1i1.678

IJIEMS This work is licensed under a Creative Commons Attribution 4.0 International License. 
International Journal of Informatics, Economics, Management and Science

http://journal.stmikjayakarta.ac.id/index.php/ijiems

E-ISSN: 2809-8471 (online), P-ISSN: 2809-9281 (Print)

DOI: $10.52362 /$ ijiems.v1i1.678

Volume 1, Issue 1, January 2022, page 13-31
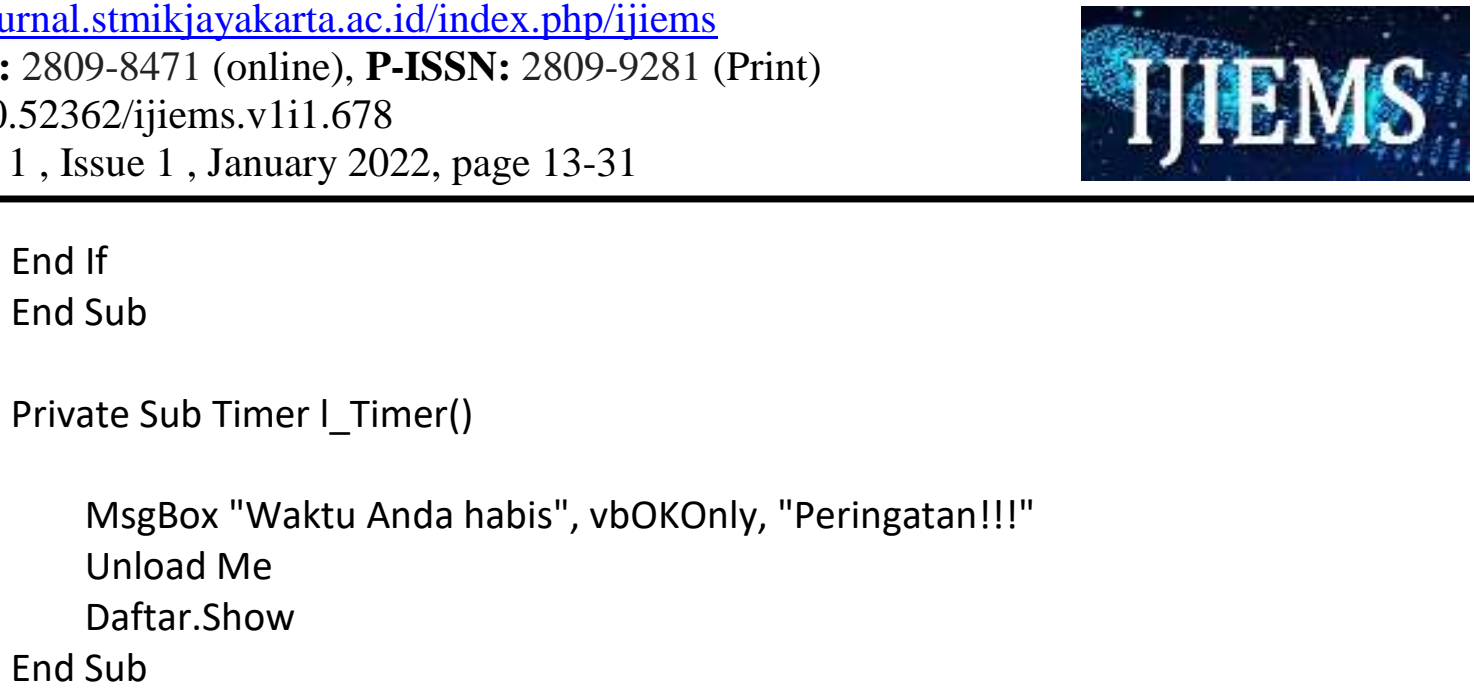

While the display form of the test menu for the Ishihara test can be seen in figure 3.2 below.

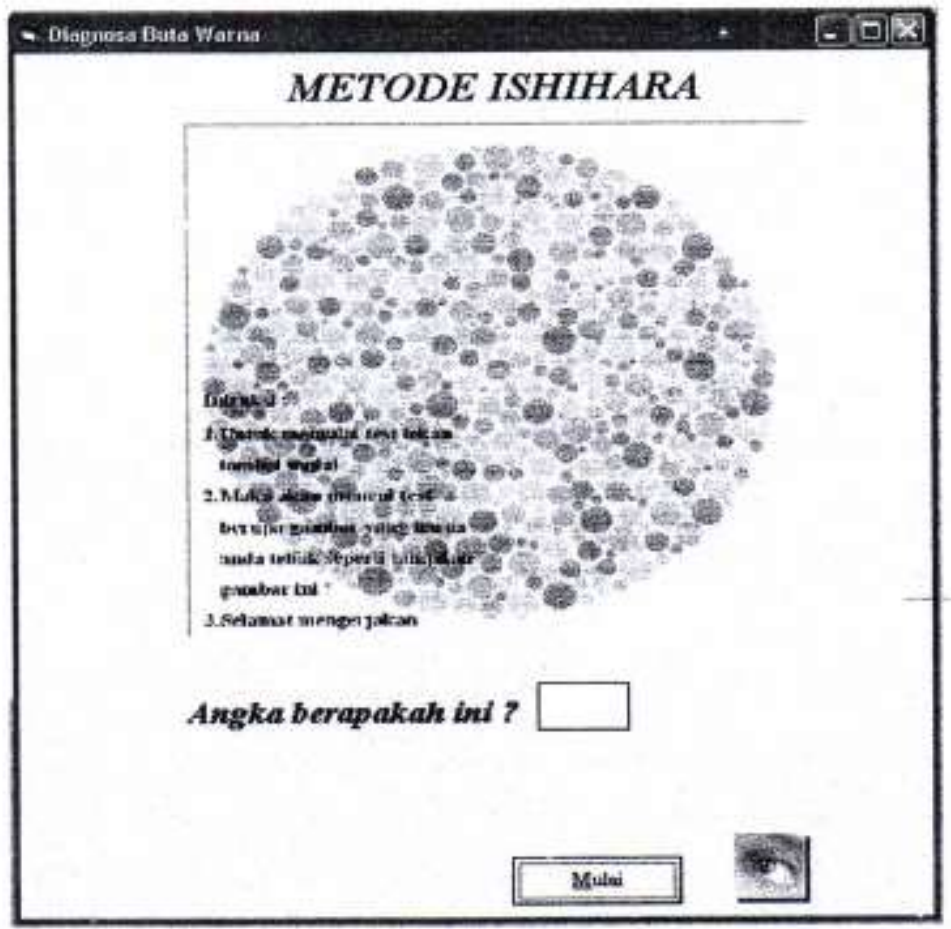

Figure 3.2 Test Menu

In this form the participant's number and name by itself will appear the identity of the participant will then be equipped by the user himself or by the system operator, here is also a command to see from the beginning of the test participant and the last test participant that will be stored in the Microsoft Access with save and delete commands that are useful for deleting and saved also edit

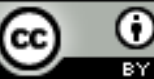

DOI: $10.52362 /$ ijiems.v1i1.678

IJIEMS This work is licensed under a Creative Commons Attribution 4.0 International License. 
International Journal of Informatics, Economics, Management and Science

http://journal.stmikjayakarta.ac.id/index.php/ijiems

E-ISSN: 2809-8471 (online), P-ISSN: 2809-9281 (Print)

DOI: $10.52362 /$ ijiems.v1i1.678

Volume 1 , Issue 1 , January 2022, page 13-31

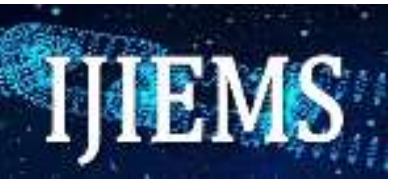

commands to fix if there is an error in the case of filling data before finally printed by the printer using a crystal report so that if there is an error in writing can be corrected. Here is the program writing code from the biodata menu form:

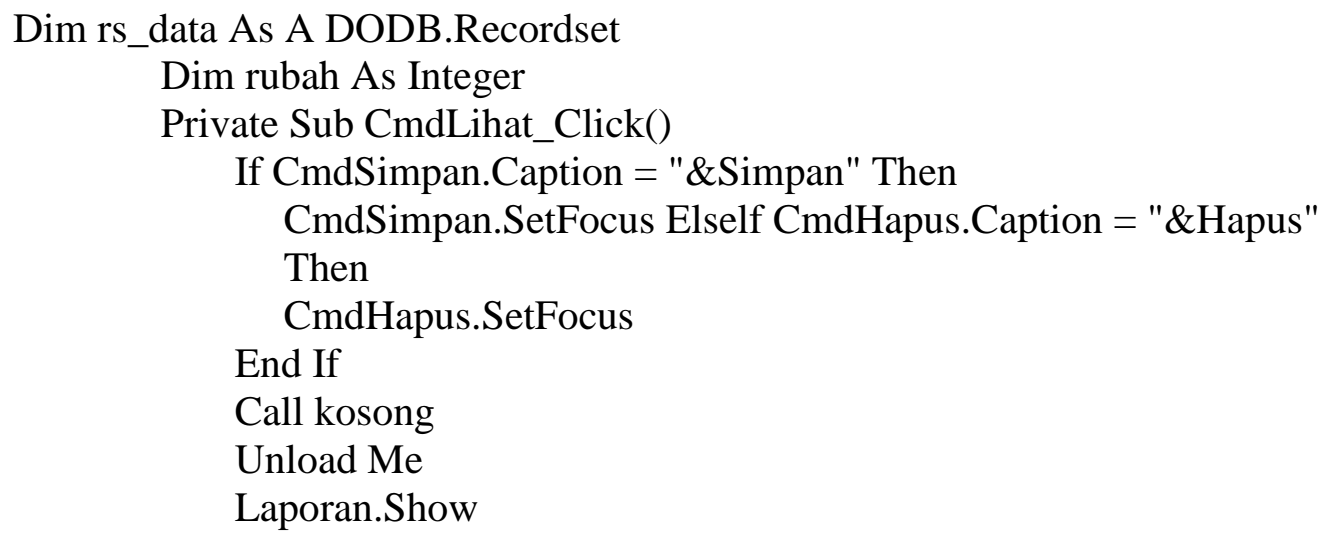

End Sub

Private Sub CmdSimpan_Click()

Simpan

End Sub

Private Sub CmdLanjut_Click(Index As Integer)

If rs_data.RecordCount $>0$ Then

If rs_data.AbsolutePosition = rs_data.RecordCount Then

MsgBox "Anda sudah berada pada posisi data paling akhir", vbInformation, "Peringatan!!!"

Exit Sub

Else

rs_data.MoveNext

End If

End If

isi

End Sub

Private Sub CmdBalik_Click(Index As Integer)

If rs_data.RecordCount $>0$ Then

If rs_data.AbsolutePosition $=1$ Then

DOI: $10.52362 /$ ijiems.v1i1.678

IJIEMS This work is licensed under a Creative Commons Attribution 4.0 International License. 
International Journal of Informatics, Economics, Management and Science

http://journal.stmikjayakarta.ac.id/index.php/ijiems

E-ISSN: 2809-8471 (online), P-ISSN: 2809-9281 (Print)

DOI: $10.52362 /$ ijiems.v1i1.678

Volume 1, Issue 1, January 2022, page 13-31

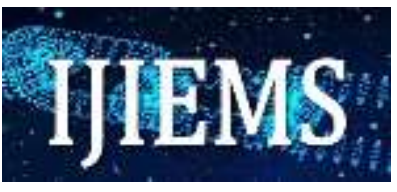

MsgBox "Anda sudah berada pada posisi data paling awal", vblnformation, "Peringatan!!!"

Exit Sub

Else

rs_data.MovePrevious

End If

End If

Isi

End Sub

Private Sub CmdHapus_Click()

Hapus

End Sub

Private Sub CmdEdit_Click()

If CmdEditCaption = "\&Edit" Then

Aktif

rubah $=1$

Textl.SetFocus

Else

Nonaktif

End If

End Sub

Private Sub Form_Load()

Adodc 1 .ConnectionString =

"Provider=Microsoft.Jet.OLEDB.4.0;Persist Security Info=False; Data

Source-" \& App.Path \& "\Database1.mdb"

Adode1.RecordSource $=$ "SELECT $*$ FROM tablel order by NoPer"

Adodc 1.Refresh

Textl $=$ Daftar.NoPer

Text2 = Daftar.Nama

Combol.AddItem "Laki-laki"

Combo1.AddItem "Perempuan"

Combo2.AddItem "Belum nikah"

Combo2.AddItem "Nikah"

Text9 $=$ Test.keterangan

Set rs_data $=$ Adodc1. Recordset

End Sub

DOI: $10.52362 /$ ijiems.v1i1.678

IJIEMS This work is licensed under a Creative Commons Attribution 4.0 International License. 
International Journal of Informatics, Economics, Management and Science

http://journal.stmikjayakarta.ac.id/index.php/ijiems

E-ISSN: 2809-8471 (online), P-ISSN: 2809-9281 (Print)

DOI: $10.52362 /$ ijiems.v1i1.678

Volume 1, Issue 1, January 2022, page 13-31

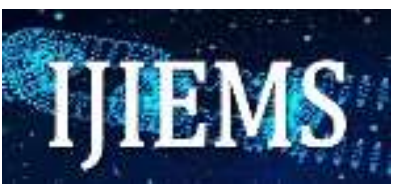

\section{Sub simpan()}

If Len(Textl) $<>0$ Or Len(Text2) $<>0$ Or Len(Combol) $<>0$ Or

Len $\left(\right.$ Text4) $<>0$ Or Len(Combo2) $<>0 \_<>0$ Or Len(Text6) $<>0$ Or

Len(Text7) $<>0$ Or Len(TextS) $<>0$ Or Len(Text9) Then

If rubah $=0$ Then rs_data.AddNew

rs_data("NoPer") = Text1.Text

rs_data("Nama") = Text2.Text

rs_data("Jenis Kelamin") = Combo1.Text

rs_data("Tempat / Tgl Lahir") = Text4.Text

rs_data("Status") = Combo2.Text

rs_data("Agama") = Text6.Text

rs_data("Alamat") = Text7.Text

rs_data("Telepon") = TextS.Text

rs_data("Keterangan") = Text9.Text

If rubah $=0$ Then

rs_data. Update

Elself rubah $=1$ Then

rs_data.UpdateBatch

End If

MsgBox "Data sudah disimpan", vbInformation, "Peringatan!!!"

kosong

table1

Else

MsgBox "Data belum lengkap", vblnformation, "Peringatan!!!"

Textl.SetFocus

Exit Sub

End If

\section{End Sub}

Sub hapus()

On Error Resume Next

Dim Tanya

Tanya = MsgBox("Yakin akan menghapus data?", vbOKCancel, "Peringatan!!!")

If Tanya $=$ vbOK Then

rs data. Delete

Adodc1.RecordSource $="$ Select $*$ From table 1 Order By

NoPer"

Adodcl.Refresh

Set rs_data $=$ Adodcl. Recordset 
International Journal of Informatics, Economics, Management and Science

http://journal.stmikjayakarta.ac.id/index.php/ijiems

E-ISSN: 2809-8471 (online), P-ISSN: 2809-9281 (Print)

DOI: $10.52362 /$ ijiems.v1i1.678

Volume 1, Issue 1, January 2022, page 13-31

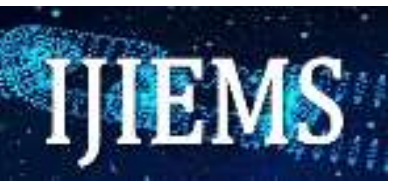

\section{Isi \\ table 1 \\ End If}

Call kosong

End Sub

For the view of the Biodata menu form can be seen in figure 3.3 below.

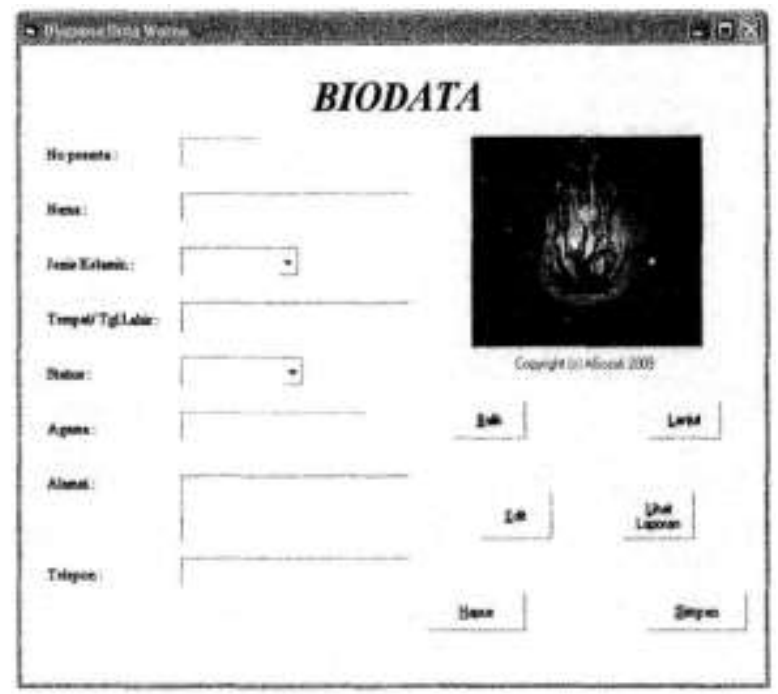

Figure 3.3 Biodata Menu

\section{Conclusion}

From the results of this study, of course, the design of the application of the expert system program to diagnose color blindness in the human eye with the Ishihara method that has been done, it can be concluded as follows:

1. The application program of the expert system of color blindness diagnosis in the human eye allows users to know directly whether he is a colorblind person or not, without having to go to the hospital.

2. This expert system application program has an attractive interface display and has a fixed light content on the monitor screen with standard specifications that make the image visible.

DOI: $10.52362 /$ ijiems.v1i1.678

IJIEMS This work is licensed under a Creative Commons Attribution 4.0 International License. 
International Journal of Informatics, Economics, Management and Science

http://journal.stmikjayakarta.ac.id/index.php/ijiems

E-ISSN: 2809-8471 (online), P-ISSN: 2809-9281 (Print)

DOI: $10.52362 /$ ijiems.v1i1.678

Volume 1, Issue 1, January 2022, page 13-31

\section{Acknowledgements}

Thank all the teams to help in completing this research, especially the academic community and the head of STMIK Jayakarta, who allowed the research to be carried out in computer laboratories and libraries.

\section{References}

[1] Kusumo Suryo, Ario, Drs. Buku Latihan Pemrograman Visual Basic 2005, Elex Media Komputindo, Jakarta, 2006.

[2] Mangkulo, Alexander Hengky. Membangun Sistem Database dengan Visual Basic 6.0, PT. Elexmedia Komputindo, Jakarta, 2003.

[3] Alam, Agus. Microsoft Visual Basic 6.0, PT.Cetakan Kelima. Elex Media Komputindo, Jakarta, 2002.

[4] Yuswanto, Pemrograman Grafis Dan Multimedia, Prestasi Pusaka, Surabaya, 2002.

[5] Kurniadi, Adi. Pemrograman Microsoft Visual Basic 6.0, PT. Elexmedia Komputindo, Jakarta, 1999.

[6] Ilyas, Sirdata, Prof, dr. llmu Penyakit Mata. Fakultas Kedokteran Universitas Indonesia, Jakarta, 1997.

[7] Simanjuntak, Gilbert WS, Dr, Sp, M. Buku Petunjuk Tes Buta Warna. Papas Sinar, Sinanti, Jakarta, 1998.

[8] Leitman, Mark W. MD. Panduan Diagnosa Dan Pemeriksaan Mata, PT. Binarupa Aksara, Jakarta, 1993.

[9] Azmi, Zulfian and Yasin, Verdi (2017) "Pengantar Sistem Pakar dan Metode", Jakarta: Mitra Wacana Media, Edisi pertama.

[10) Yasin, Verdi (2012) "Rekayasa Perangkat Lunak Berorientasi Objek”, Jakarta: Mitra Wacana Media, Edisi Pertama. 